\title{
PENETRATION AND STRESS-STRAIN BEHAVIOR OF POTATO TUBERS DURING STORAGE
}

\author{
Soliman N. Soliman ${ }^{1}$ and Azhar El-Wersh El-Sayed ${ }^{2}$
}

ABSTRACT

The aim of this investigation is to study the Penetration and stress-strain behavior of Lady Rosetta potato tubers variety as destructive tests under different storage conditions. An Instron machine was used for stressstrain tests. Force deformation tests of fresh potato tuber show that the small tubers have a more strength than that for big tubers for each soil cultivars. The fresh harvested tubers tend to be very brittle. Because of their brittleness, potato tubers tissues were cracked under compression test. The result appears that yield strain, increases gradually with increasing storage time. Rupture force, rupture strain, rupture stress, and toughness decreases gradually with increasing storage time. Yield force, yield stress, resilience, initial modulus of elasticity and secant modulus of elasticity decreases gradually with increasing storage time. Penetration forces $(N)$ of fresh tubers were measured. The penetration force was ranged from 19.080 to 26.389 within average of 22.306 for sand soil cultivars, while ranged from 18.246 to 32.785 with an average of 24.413 for black soil cultivars, using probe of $3.8 \mathrm{~mm}$ diameter.

\section{INTRODUCTION}

$\mathrm{P}$ otatoes are considered as one of the most important vegetables crops in Egypt, which is one of the largest producers and exporters of potatoes in Africa. Potato is the second most important vegetable crop after tomato. According to the NPC, Jul 2016 (National Potato Council, Washington, D.C., USA), the Egyptian production of potatoes increased from 2.3 million tons in 2006 to 4.8 million tons in 2014) for the total area of 1.77 million hectare.

Harvesting, handling and storage of potatoes produces several mechanical injuries. There for the study of mechanical property is very important for improving the technology of these processes. Storage processes produce stresses effect and bring about physiological changes and water loss, which in turn affect the mechanical properties (Burton. 1989).

1- Prof. of Food Engineering, Faculty of Agriculture, Alexandria Univ.

2- Researcher at Agricultural Engineering Research Institute, Agricultural Research Center, Ministry of Agriculture Egypt. 
Mohsenin (1986) mentioned that mechanical damage in agricultural products is due to external forces and internal forces. External forces affect fruits or vegetables when they are subjected to several static and dynamic loads causing mechanical injuries, while internal forces may be a result of physical changes, such as variations in temperature and moisture content, or a result of chemical and biological changes.

Fekete and Sass (1994) examined the use of coefficient of elasticity (ratio of compressive force to the deformation) as a measure of fruit firmness. They found a good correlation between the coefficient of elasticity and other mechanical properties (bioyield and rupture stress, and the Young's modulus of elasticity) which confirms the possibility of using that property for apple firmness.

Puncture testers based on the original Magness-Taylor pressure (MT) tester are used to measure firmness of potato tubers to estimate harvest maturity or for postharvest evaluation of firmness.

Konstankiewicz et al. (2001) studied the influence of structural parameters of potato tuber tissue on its mechanical properties. Stressstrain tests were carryout with constant rate $5 \mathrm{~mm} \mathrm{~min}^{-1}$. The parameters of the structure such as: cell area and cell perimeter, exert a significant influence on mechanical parameters, i.e., strength and modulus of elasticity.

Baritelle and Hyde (1999) conducted research on the failure of potato tubers during dynamic axial compression test at strain rate1/80 $\mathrm{S}^{-1}$ and at temperature $8^{\circ} \mathrm{C}$. Results showed that tubers over $340 \mathrm{~g}$ were significantly less tough than those under $170 \mathrm{~g}$, while tubers between $170 \mathrm{~g}$ and $340 \mathrm{~g}$ did not have significant different failure properties.

The objective of this research is to measure the mechanical properties of fresh and storied potato tubers and study the effect of potato size, storage conditions and storage times on the change of their mechanical properties by using each of penetration test and force deformation test, these measurements are indicator of texture strength to withstand mechanical post-harvesting processes.

\section{MATERIAL AND METHODS}

Samples of fresh potato variety "Lady Rosetta" which was planted under two different soils sandy soil and black soil, each of 500 kilograms were provided from Daltex company in Kafr El-Zaiat. 
The fresh potato tubers were manually harvested carefully by hand, cleaned from soiland the dameged tubers were excluded manually, and transported in the same day to the laboratory of food engineering fucalty of agriculture Alexandria University.

The potato tubers were classifieds into three different size small "tubers mass of 70 to $<100 \mathrm{~g}$ ", medium " tubers mass of 100 to $<130 \mathrm{~g}$ " and large " tubers mass of $\geq 130 \mathrm{~g}$ ".

The selected tubers from each size were numbered for preparation and recording the physical measurements, including tuber mass, dimension (length, width and thickness), volume, bulk and particle density, surface area, respiration rate, moisture content and sugar contents.

The moisture content, wet base $\%$ of fresh and stored potato tubers were conducted according to Ghadgeet al., 1989.

Tuber mass was measure using electronic weighing balance model Acclab LT 3200 with maximum scale of 3200 grams and with accuracy of 0.01 grams, and the tuber dimensions were measure using electronic digital caliper model MAX-CAL, with an accuracy of $0.01 \mathrm{~mm}$.

Tuber's spherecity, Bulk density, moisture content wet base \% and sugar content (Brix) were measured according to Mohsenin1986. Six replicates measurements for each category and for each of sand soil and black soil. Two storage chambers were prepared for conducting storage treatments of potato tubers at Agricultural Engineering Department, Faculty of Agriculture, Alexandria University. The first type is traditional storage chamber (Al-Nawalla). The second type is refrigeration chamber which used for each of curing potatoes at $15 \mathrm{oC}$ and $90 \%$ relative humidity for 15 days and for long storage of potatoes at $8 \mathrm{oC}$ and $85 \%$ relative humidity.

The storage was done under three levels of static pressure " 0.0, 2.44 and $4.87 \mathrm{kPa}$, which was exerted on the top of the potato cage. The amount of 36 storage treatments including 6 potato samples which were subjected for 6 storage conditions were done in five replicates.

\subsection{Experimental Measurements}

The mechanical properties tests are included each of penetration test and force-deformation test as destructive tests.The penetration test was carried out as an indicator for estimating the degree of freshness, the 
change of the initial quality and shelf life during storage or decay of skin and tissue of potato tubers. The force-deformation test was done to determine both the initial modulus of elasticity E1 and secant modulus E2, MPa, stiffness, bio-yield stress, resilience, rupture point, and toughness of potato tubers.

The controller test was done on about 20 tubers which were selected from each of the three mentioned size grade.

\subsubsection{Penetration Test}

Penetration tests were carried out by using an Italian fruit pressure tester (FT 011) figure (1). Two penetration steel pins with the actual diameters of 3.8 and $2.0 \mathrm{~mm}$. were used. These tests were done to penetrate potatoes texture in five replicates.

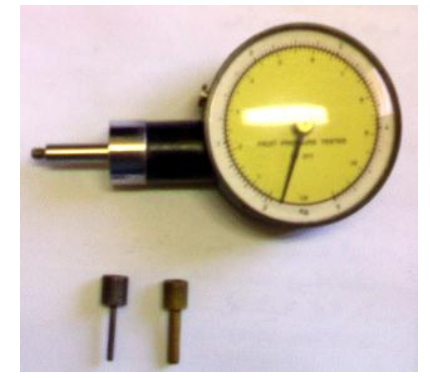

Figure (1) Penetration tester (FT 011).

The collected data were compared for both penetrations pin to find some relation between the effective force and the used pin size. Thus, the effect of storage on the penetration properties for the tested tubers can study. The penetration force (PF, N) of 120 fresh potato tubers including 20 tubers from each tuber mass group and each soil cultivar was determine.

\subsubsection{Stress-Strain test}

The Stress-Strain tests were carried out by using an Instron Machine Cole Parmer model (G-08232-28) as shown in figures (2), with applied force ranged from 0.0 to 1818 kilograms and crosshead speed ranged from 5 to $100 \mathrm{~mm} / \mathrm{min}$. The tests in this study were carried out at crosshead speed of $20 \mathrm{~mm} / \mathrm{min}$.

This machine was provided with two cylindrical plungers having the same diameter of two centimeters to be suitable for potato tubers tests. These plungers were fixed to the upper and lower plates. The force-deformation test was run by placing a whole potato tuber between the two parallel 
plungers, the tuber was placed at its rest position, which it is maximum thickness in the loading direction under the plunger. The force was applied on the upper plunger by the press of the crosshead, which was moved down at the selected speed $(20 \mathrm{~mm} / \mathrm{min})$ deforming the sample until the failure was achieved. The stress was calculated as follows:

$$
\text { Stress }=\frac{4 \mathrm{~F}}{\pi D^{2}}
$$

Where: $\mathrm{F}=$ force, $\mathrm{kg}, \mathrm{D}=$ plunger diameter, $\mathrm{cm}$

The strain calculated by dividing the deformation of the sample by the initial maximum thickness of the sample. The mechanical properties parameters associated with the stress-strain data were determined.

For stress-strain, tests figure (3), the initial modulus of elasticity $\left(\mathrm{E}_{0}\right)$ in MPa calculated as the initial slope of the stress-strain curve before straight

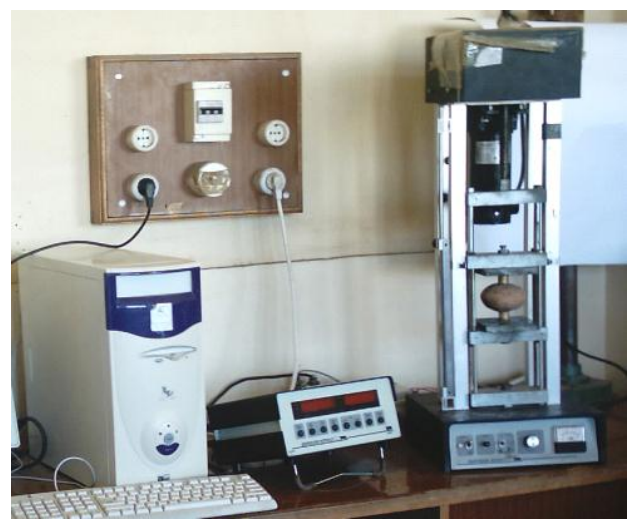

Figure (2) Instron Machine Cole Parmer model (G-08232-28)

line. While, the modulus of elasticity (E) in MPa calculated as the slope of the stress-strain curve at the stage appear to be straight line. Secant modulus of elasticity up to yield point of potato tubers (E2, MPa) was determined. Toughness $\left(\mathrm{WD}_{\mathrm{r}}\right.$, Joul), of potato tuber as the energy required to reach rupture point during the elastic and plastic region, was determined as the area under the stress strain curve up to the rupture point using limited integration by trapezoidal method. Failure energy $\left(\mathrm{MJ} / \mathrm{m}^{3}\right)$ was calculated as the area under stress-strain curve until rupture point and the horizontal axis. Resilience $\left(\mathrm{WD}_{\mathrm{y}}\right.$, Joule) of potato tuber as the energy required to reach yield point during the elastic region was determined as 
the area under the stress strain curve up to the yield point using limited integration by trapezoidal method. All stress-strain tests for the studied varieties were included five replicates.

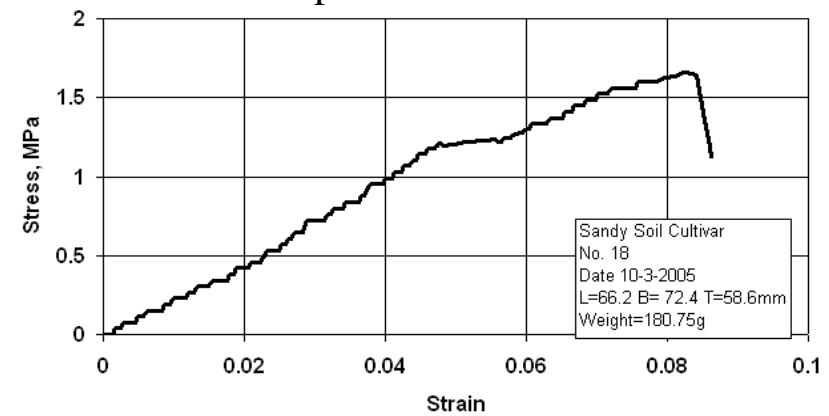

Figure (3) Typical Stress-Strain Curve of Fresh Lady Rosetta Tubers

\section{RESULTS AND DISCUSSION}

\subsection{Mechanical Behavior of Fresh Potatoes:}

\subsubsection{Penetration test}

The results of penetration force $(\mathrm{PF}, \mathrm{N})$ and penetration stresses (PS, $\mathrm{MPa}$ ) which were measured and represented in figure (4) using the two probes for sand soil and black soil.

The penetration forces, stresses and the mean values presented in Table (1).

The statistical analyses of penetration force and stress results appear a random distribution with a decreasing general trend with tuber mass. The results appear that the black soil tubers are more resistible for penetration than sandy soil tubers.

\subsubsection{Stress Strain test}

The total numbers of 240 Stress-Strain tests were carried out on fresh potato tubers individually including 40 tubers of each mass group and 120 tests for each soil cultivars.

The fresh harvested tubers tend to be very brittle. Because of their brittleness, potato tubers tissues were cracked under compression test.

This behavior influenced by the mechanical properties of the cell walls, as well as by adhesion between cells and the turgor pressure within the cells. Figure (5) represent the crack behavior of fresh potato tuber under compression stress during stress-strain test. 

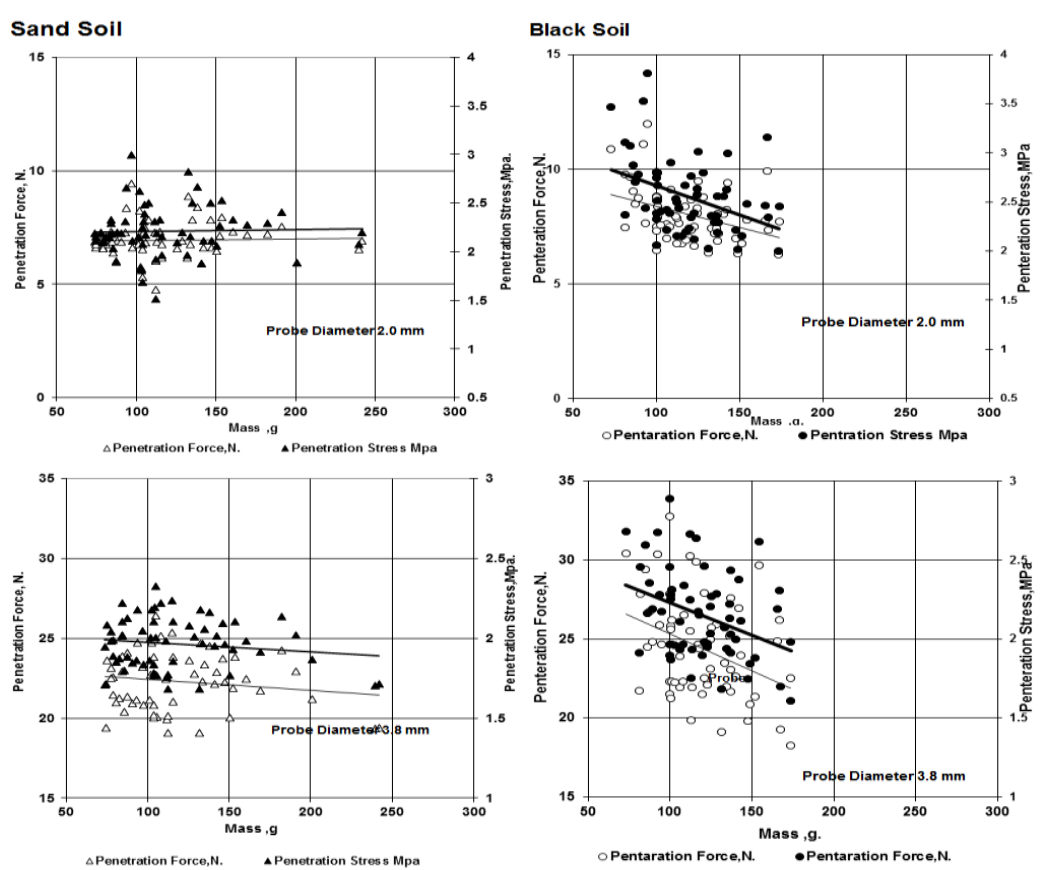

Figure (4) Penetration Force and Penetration Stress of Fresh Sand and Black Soil Potato Tubers.

Table (1): Penetration forces and Stresses of Fresh Potato

\begin{tabular}{|c|c|l|l|l|l|l|l|}
\hline Cultivars & Prope & \multicolumn{3}{|c|}{ Force, N. } & \multicolumn{3}{c|}{ Stress, MPa } \\
\cline { 3 - 8 } & Diameter & Max. & Min. & Mean & Max. & Min. & Mean \\
\hline Sand & $2 \mathrm{~mm}$. & 9.418 & 4.758 & 6.939 & 2.998 & 1.515 & 2.209 \\
\cline { 2 - 8 } Soil & $3.8 \mathrm{~mm}$. & 26.389 & 19.081 & 22.305 & 2.327 & 1.682 & 1.967 \\
\hline Black & $2 \mathrm{~mm}$. & 11.968 & 6.278 & 8.022 & 3.809 & 1.998 & 2.554 \\
\cline { 2 - 8 } Soil & $3.8 \mathrm{~mm}$. & 32.785 & 18.247 & 24.413 & 2.891 & 1.608 & 2.153 \\
\hline
\end{tabular}

Tables $(2,3)$ summarized the statistical description of mechanical parameters of fresh potato related to the stress-strain test at each of bioyield point and rupture point.

Figures $(6,7$, and 8$)$ represent the mechanical properties of fresh potato tuber for each of sand and black soils cultivars.

The results show that the small tubers have a more strength than that for big tubers for each soil cultivars. This behavior was agreed with Konstankiewicz and Zdunek, 2001 which mentioned to potato tuber with smaller cells has higher strength in comparison to bigger cells, and also agreed with Baritelle and Hyde, 1999 which found that the mechanical 
properties of potato tubers can be attributed to the physiological characteristics of the tuber, i.e. size, shape and volume.

\section{Elevation}
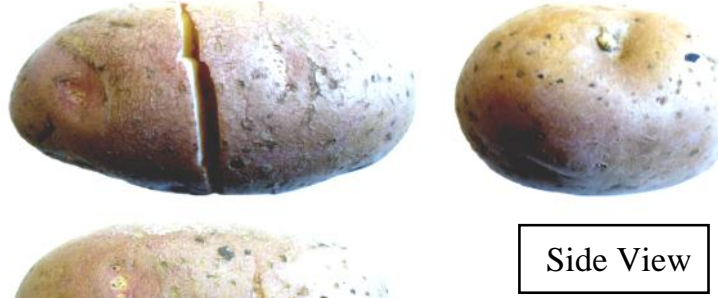

Plane

Figure (5) Cracked Potato Tubers in Three Directions After Force Deformation Test.

Table (2): Force Deformation test parameters of Potato tuber at yield Point

\begin{tabular}{|c|c|c|c|c|c|c|c|}
\hline Cultivar & \begin{tabular}{|c} 
Data \\
Analysis
\end{tabular} & $\begin{array}{c}\text { Yield } \\
\text { ForceF }_{\mathbf{y}}, \\
\mathbf{N}\end{array}$ & $\begin{array}{c}\text { Yield } \\
\text { Stress } \sigma_{\mathrm{y}} \mathrm{MPa}\end{array}$ & \begin{tabular}{|c||} 
Yield \\
Strain, $\varepsilon_{\mathrm{y}}$
\end{tabular} & \begin{tabular}{|c|} 
Resilience, \\
WD $_{\mathbf{y}}$ \\
,Joule.
\end{tabular} & \begin{tabular}{|c}
$\mathbf{E}_{1}$, \\
MPa.
\end{tabular} & $\begin{array}{c}\mathbf{E}_{2}, \\
\mathbf{M P a}\end{array}$ \\
\hline \multirow{3}{*}{\begin{tabular}{|l} 
Sand \\
Soil
\end{tabular}} & Mean & 444.276 & 1.4142 & 0.190 & 2.237 & 4.328 & 7.355 \\
\hline & Minimum & 323.327 & 1.029 & 0.127 & 1.060 & 2.385 & 5.319 \\
\hline & Maximum & 574.805 & 1.829 & 0.229 & 3.538 & 7.89 & 9.764 \\
\hline \multirow{3}{*}{\begin{tabular}{|l|} 
Black \\
Soil
\end{tabular}} & Mean & 488.834 & 1.556 & 0.212 & 2.642 & 5.342 & 8.344 \\
\hline & Minimum & 371.228 & 1.182 & 0.106 & 1.536 & 1.678 & 3.567 \\
\hline & Maximum & 646.655 & 2.058 & 0.335 & 4.523 & 15.175 & 16.975 \\
\hline
\end{tabular}

Table (3): Force Deformation test parameters of Potato tuber at Rupture Point.

\begin{tabular}{|c|c|c|c|c|c|}
\hline Cultivar & $\begin{array}{l}\text { Data } \\
\text { Analysis }\end{array}$ & $\begin{array}{c}\text { Rupture } \\
{\text { Force } \mathrm{F}_{\mathrm{r}}, \mathbf{N}}\end{array}$ & $\begin{array}{c}\text { Rupture } \\
\text { Stress } \sigma_{\mathrm{r}, \mathbf{M P a}}\end{array}$ & $\begin{array}{l}\text { Rupture } \\
\text { Strain } \varepsilon_{\mathbf{r}}\end{array}$ & $\begin{array}{l}\text { Toughness } \\
\text { WD }_{\text {r,Joul }}\end{array}$ \\
\hline \multirow[t]{3}{*}{ Sand Soil } & Mean & 4997.166 & 1.5838 & 0.2349 & 3.6549 \\
\hline & Minimum & 407.1533 & 1.2960 & 0.1815 & 2.2333 \\
\hline & Maximum & 586.7798 & 1.8678 & 0.2793 & 6.0811 \\
\hline \multirow[t]{3}{*}{ Black Soil } & Mean & 558.9869 & 1.7793 & 0.2969 & 5.0954 \\
\hline & Minimum & 443.0786 & 1.4104 & 0.1912 & 2.4035 \\
\hline & Maximum & 670.6055 & 2.1346 & 0.4780 & 10.9289 \\
\hline
\end{tabular}

The results show that black soil cultivar appeared more strength than sand soil cultivar at each of yield point force $\mathrm{F}_{\mathrm{y}}, \mathrm{N}$ and at rupture point force. 
This is may be return to the black soil cultivar more compacted texture than sand soil cultivar.

\subsection{Mechanical Behavior of Stored Potatoes}

The mechanical behavior of potato tubers under investigation were measuring during storage period under different conditions. The penetration and force deformation tests are destructive tests and were conducted once times for each tuber.

\subsubsection{Penetration test:}

The penetration forces of 288 tubers were measured each about 45 days during storage period including, two cultivars (sand and black soil), two storage condition (cold and traditional), three mass groups, three load stress and eight replicates from each treatment. Figure (9) represent the penetration forces $(\mathrm{PF}, \mathrm{N})$ of potato tubers as a function of storage time with using two probes of $2 \mathrm{~mm}$ diameter (A) and $3.8 \mathrm{~mm}$ diameter (B) for each soil at different static load stress, and different storage conditions (cold and traditional storage).

Step wise multiple regression statistical analysis were conducted to clarify the relationship between the penetration forces for the two probes A and $\mathrm{B}(\mathrm{PF}, \mathrm{N})$ and storage potato parameters, including tubers mass $(\mathrm{M}, \mathrm{g})$, storage temperature $\left(\mathrm{T},{ }^{\circ} \mathrm{C}\right)$, storage periods (t, days) and static load stress ( $\mathrm{SL}, \mathrm{kPa}$ ) for each of sand and black soil cultivars. The step wise regression analysis clarifies that the correlation of logarithmic function of the penetration forces $(\mathrm{PF}, \mathrm{N})$ versus other parameters under study is the best fit equation. The statistical regression equations were as follow:

\section{For Sand Soils:}

$\mathrm{LN} \mathrm{PF}_{\mathrm{A}}, \mathrm{N} .=0.0250 \mathrm{~T}+0.0398 \mathrm{SL}+0.0032 \mathrm{t}+0.0097 \mathrm{M}$

$$
. \mathrm{R}^{2}=0.966, \mathrm{STD}=0.372 \ldots
$$

$\mathrm{LN} \mathrm{PF}, \mathrm{N} .=0.0379 \mathrm{~T}+0.0708 \mathrm{SL}+0.0046 \mathrm{t}+0.015648 \mathrm{M}$

$$
. \mathrm{R}^{2}=0.964, \mathrm{STD}=0.604 \ldots
$$

\section{For Black Soils:}

$\mathrm{LN} \mathrm{PF}$ A,$N .=0.0255 \mathrm{~T}+0.0515 \mathrm{SL}+0.0255 \mathrm{t}+0.0102 \mathrm{M}$

$$
. \mathrm{R}^{2}=0.960, \mathrm{STD}=0.424 \ldots
$$

$\mathrm{LN} \mathrm{PF}_{\mathrm{B}}, \mathrm{N} .=0.0381 \mathrm{~T}+0.0784 \mathrm{SL}+0.0048 \mathrm{t}+0.01580 \mathrm{M}$

$$
\mathrm{R}^{2}=0.960, \mathrm{STD}=0.646 \ldots
$$



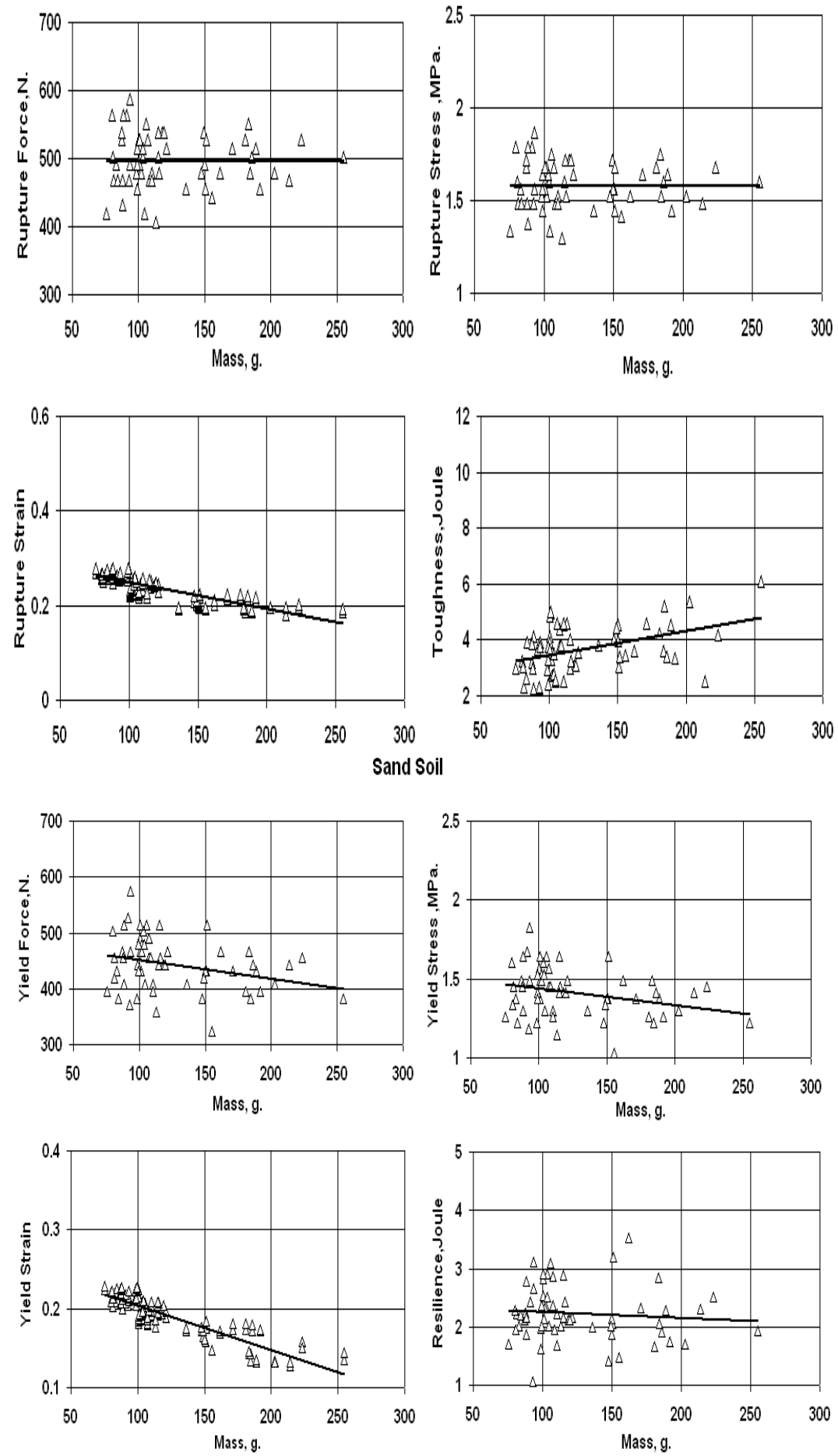

Figure (6): Mechanical Properties at Yield and at Rupture Points of Fresh Sand Soil Potato Tubers 
Black Soil
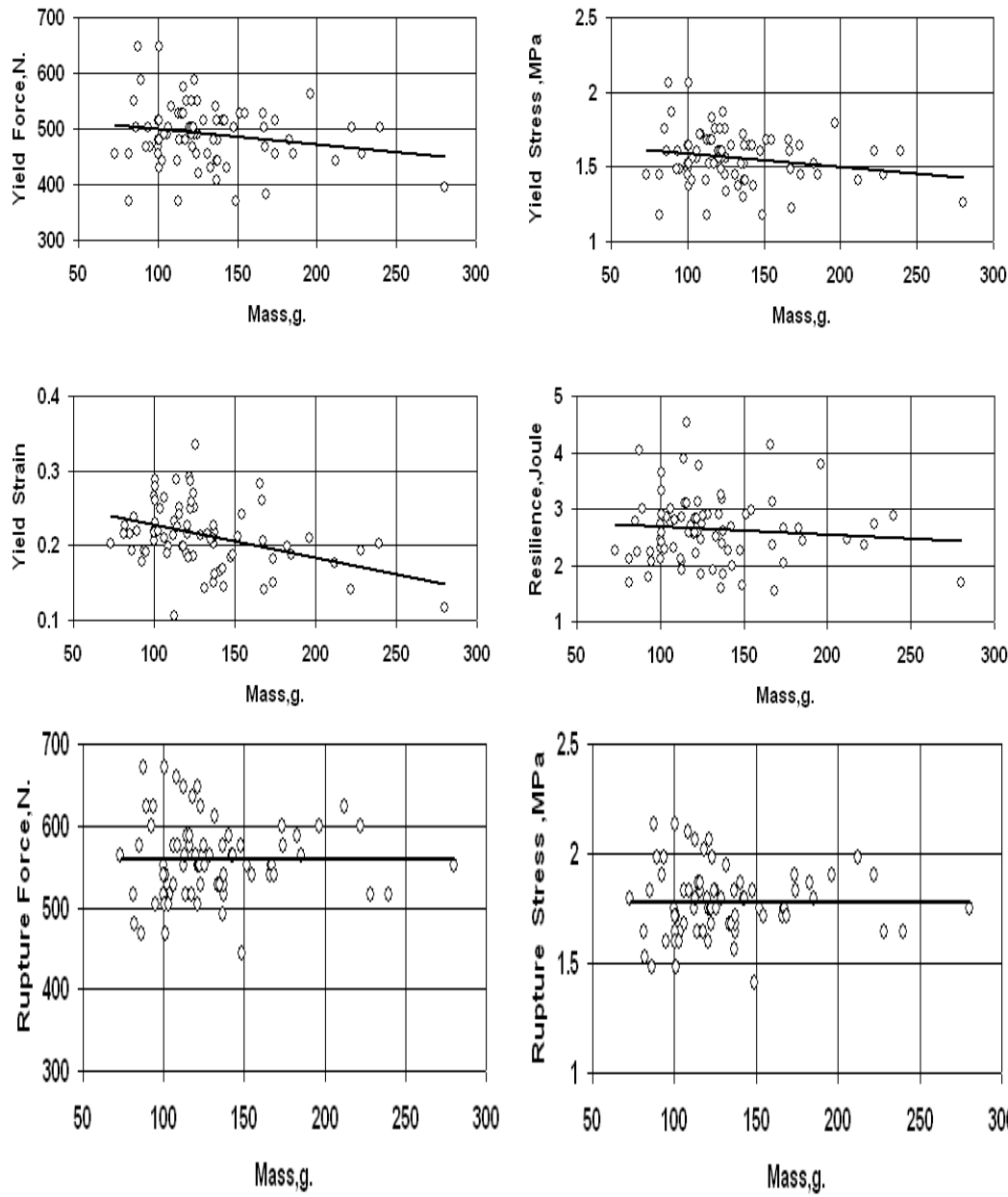

Mass,g.
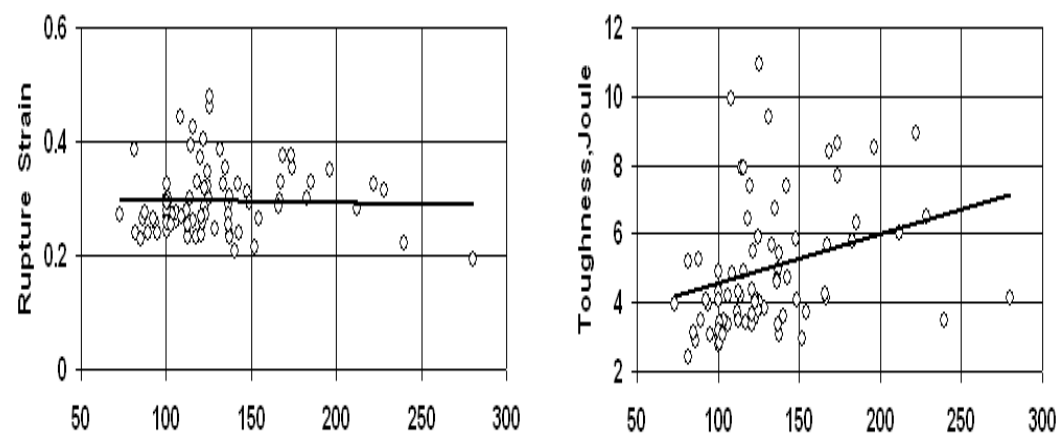

Mass,g.

Mass,g.

Figure (7) : Mechanical Properties at Yield and at Rupture Points of Fresh Black Soil Potato Tubers 

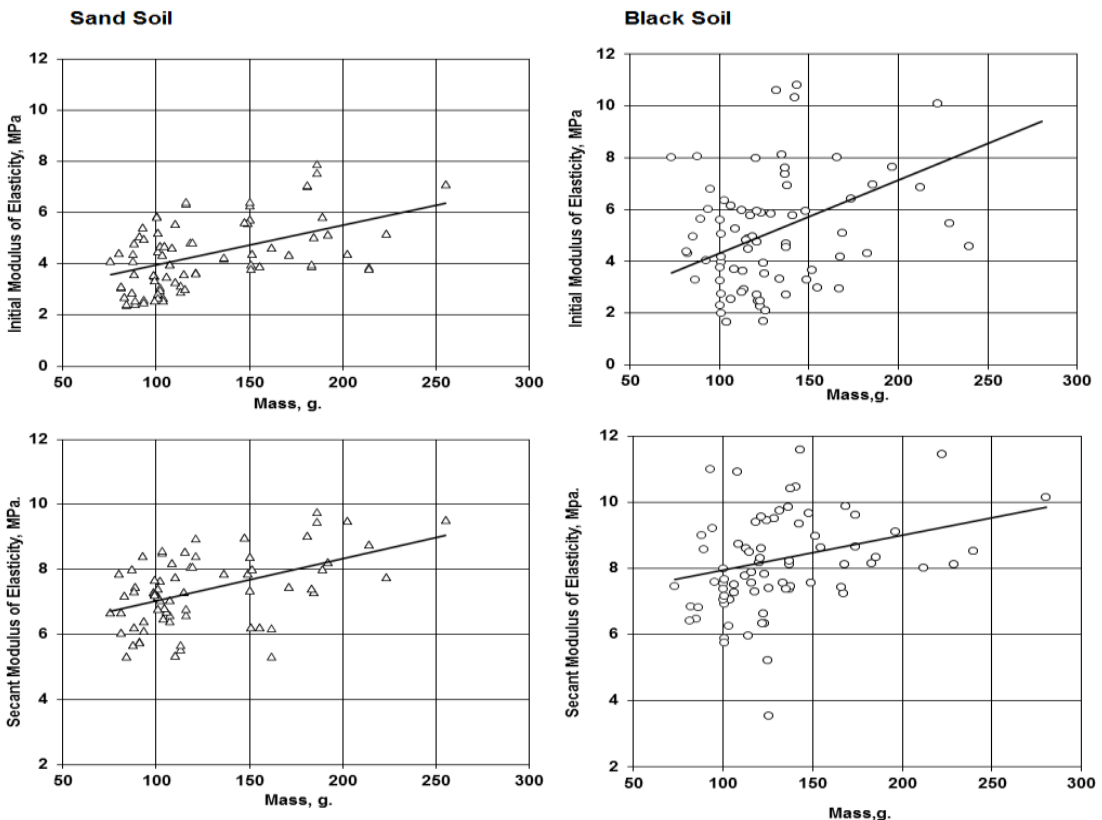

Figure (8): Initial Modulus and Secant Modulus of Elasticity for fresh Sand and Black Soil Potato Tubers

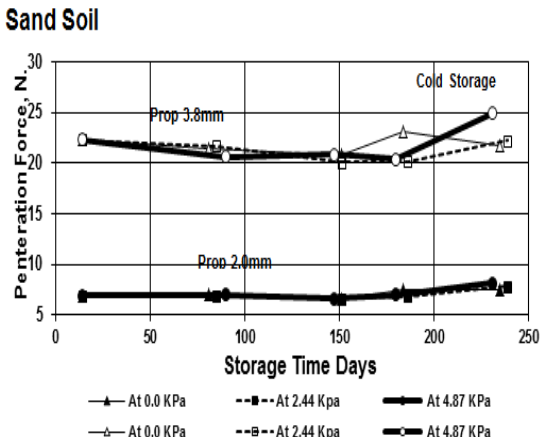

Black Soil
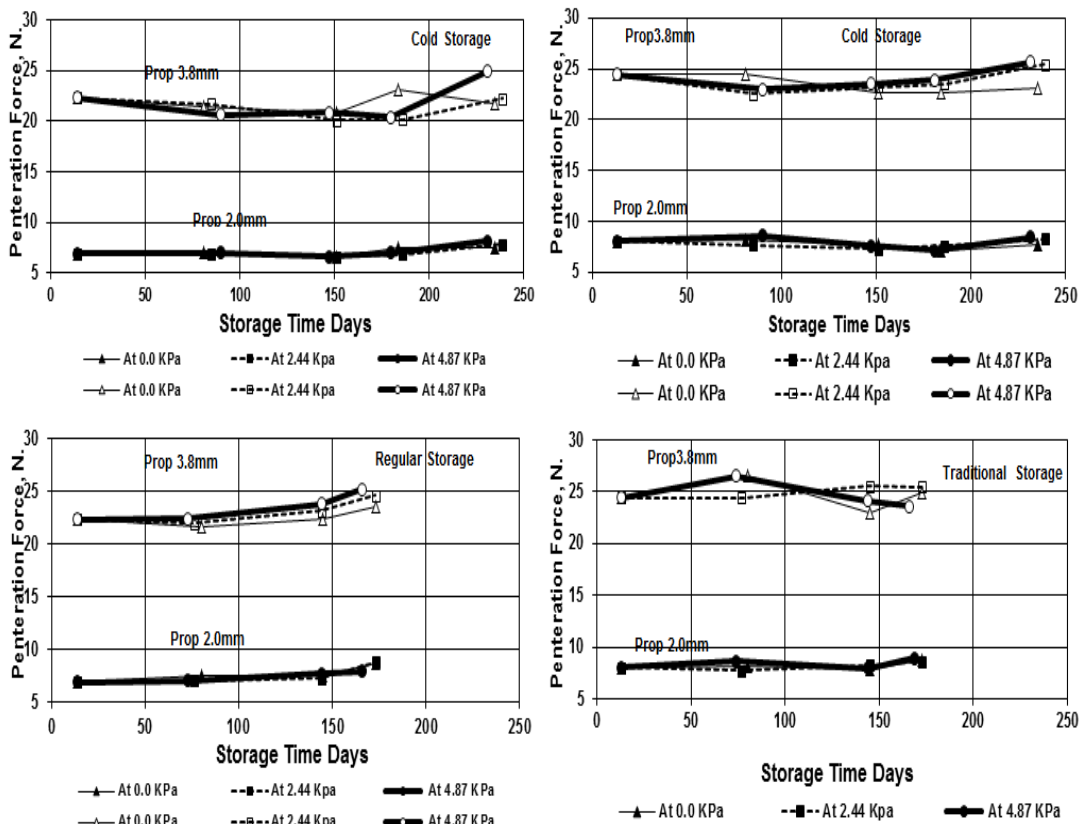

Figure (9) Penetrations Force of Sand and Black Soil Potato Tubers at Two Storage Conditions and at Different Static Stress. 
The statistical analysis show that the logarithmic function of penetration forces (PF, N) was direct proportion with storage time and other parameters under study due to the increasing of tenderness (softness) based on changes of water holding capacity and chemical composition of tubers with storage time.

\subsubsection{Stress-Strain test:}

The total numbers of 2592 force-deformation tests were carried out on storage potato tubers individually to determine parameters of mechanical properties for tubers measured including, two cultivars (sand and black soil), two storage condition (cold and traditional), three mass groups, three load stress and eight replicates from each treatment. The force deformation tests were carrying one time on each tuber at different storage time.

The stress-strain parameters (SSP) including Yield Force $\left(F_{y}, N\right)$, Yield Stress $\left(\sigma_{\mathrm{y}}, \mathrm{MPa}\right)$, Yield Strain $\left(\varepsilon_{\mathrm{y}}\right)$, Resilience, $\left(\mathrm{WD}_{\mathrm{y}}\right.$, Joule), initial and second mean Modulus of Elasticity of whole potato tubers (E1 and E2 $, \mathrm{MPa})$, Rupture Force $\left(\mathrm{F}_{\mathrm{r}}, \mathrm{N}\right)$, Rupture Strain $\left(\varepsilon_{\mathrm{r}}\right)$, Rupture Stress $\left(\sigma_{\mathrm{r}}\right.$, $\mathrm{MPa})$, and Toughness $\left(\mathrm{WD}_{\mathrm{r}}\right.$, Joul) were determined. Figures (10-12) demonstrated (SSP) as a function of storage time for each of sand and black soils cultivar for storage treatments.

The data appear that each of Yield Stress $\left(\sigma_{\mathrm{y}}, \mathrm{MPa}\right)$, Resilience $\left(\mathrm{WD}_{\mathrm{y}}\right.$, Joule), Initial modulus of elasticity (E1, MPa), Secant modulus of elasticity (E2, MPa), Rupture Force $\left(\mathrm{F}_{\mathrm{r}}, \mathrm{N}\right)$, Rupture Stress, $\left(\sigma_{\mathrm{r}}, \mathrm{MPa}\right)$, and Toughness $\left(\mathrm{WD}_{\mathrm{r}}, \mathrm{Joul}\right)$, are decreases gradually with increasing storage time. Yield Strain, $\varepsilon_{\mathrm{y}}$, Rupture Strain, $\varepsilon_{\mathrm{r}}$, of potato tubers increases gradually with increasing storage time.

Nonlinear multiple regression statistical analysis was conducted to clarify the relationship between SSP of potato tubers during storage and each of storage condition (cold and traditional temperature) at different static load stress $(0.0,2.44$ and $4.87 \mathrm{kPa})$ and at different storage periods (20, 60, 120, and 200 day) for each of sand and black soil cultivars.

The step-wise regression analysis clarifies that the linearity of SSP's, versus other parameters under study is the best fit equation. The statistical regression equations are shown as follows: 
Sand soil

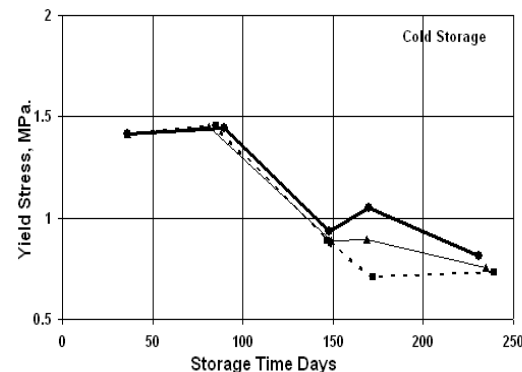

$\rightarrow$ at $0.0 \mathrm{KPa} \cdots-$ at $2.44 \mathrm{KPa} \rightarrow$ at $4.87 \mathrm{KPa}$

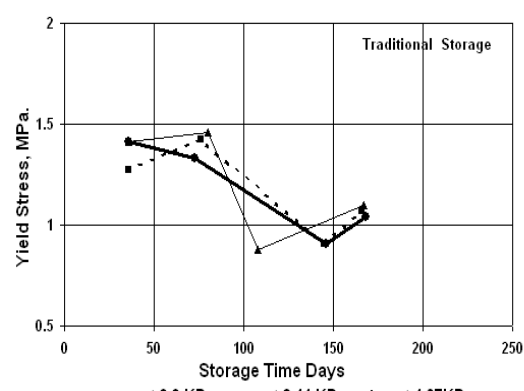

$\rightarrow$ at $0.0 \mathrm{KPa}-\cdots+$ at $2.44 \mathrm{KPa} \rightarrow$ at $4.87 \mathrm{KPa}$

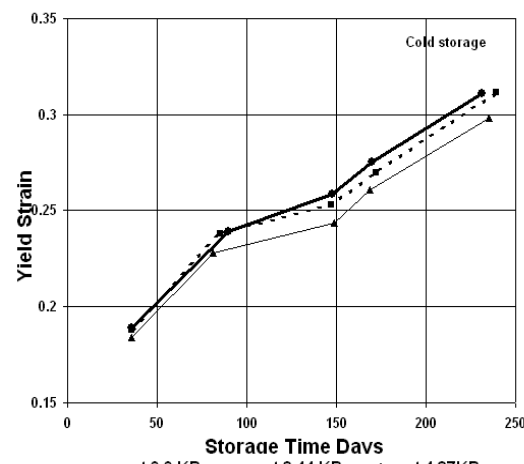

$\leftarrow$ at $0.0 \mathrm{KPa} \cdots-$ at $2.44 \mathrm{KPa} \rightarrow$ at $4.87 \mathrm{KPa}$

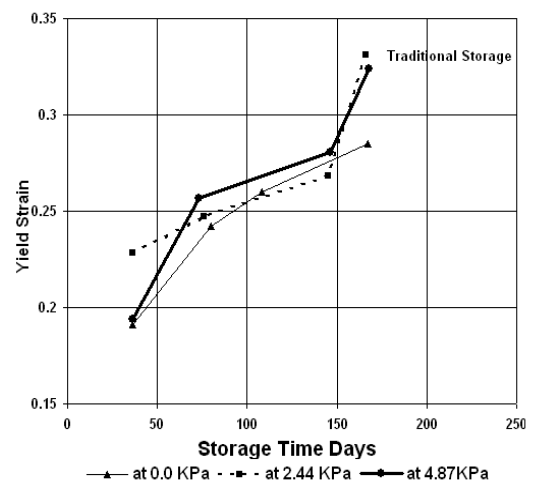

Black Soil
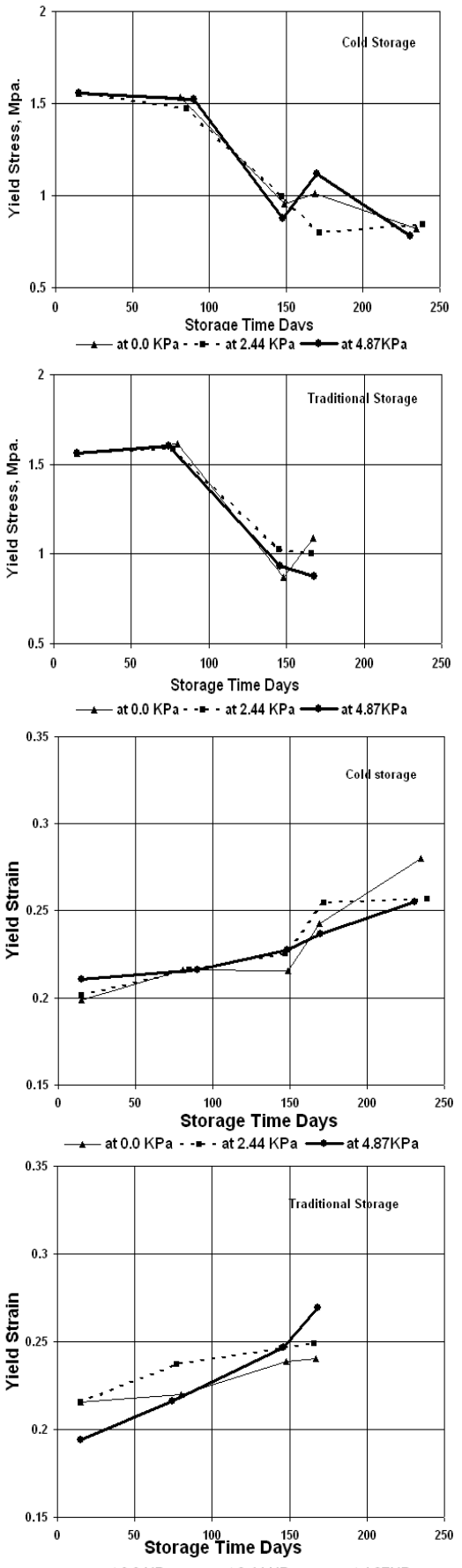

Figure (10): Yield Stress and Yield Strain of Sand and Black Soil Cultivars Versus Storage time on Two Storage Conditions and at Different Static Load. 
Sand soil

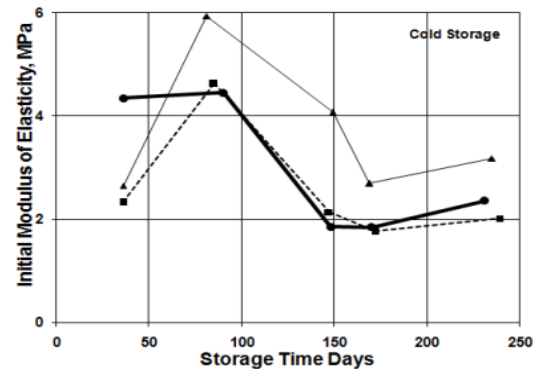

$\rightarrow$ at $0.0 \mathrm{KPa} \rightarrow-$ at $2.44 \mathrm{KPa} \rightarrow$ at $4.87 \mathrm{KPa}$
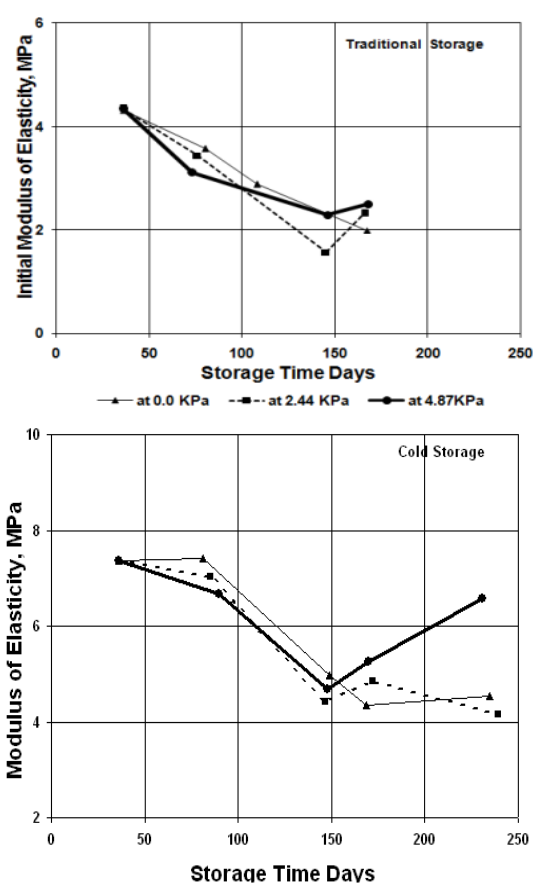

- at $0.0 \mathrm{KPa}$-..- at $2.44 \mathrm{KPa} \rightarrow$ at $4.87 \mathrm{KPa}$

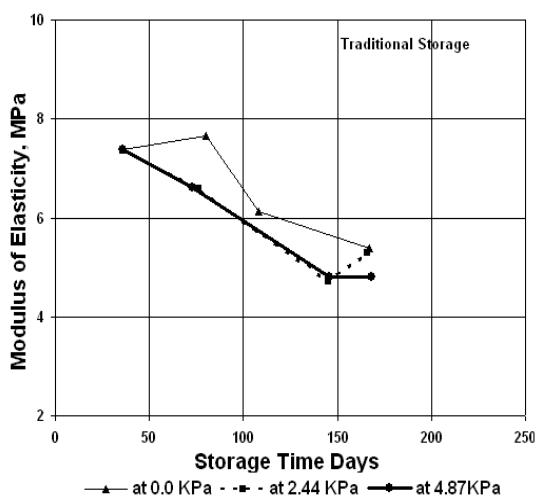

Black Soil

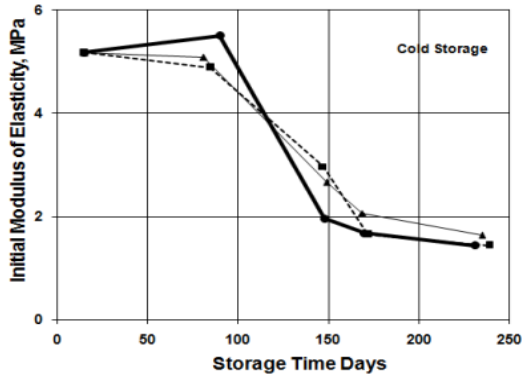

$\rightarrow$ at $0.0 \mathrm{KPa} \rightarrow-$ at $2.44 \mathrm{KPa} \rightarrow$ at $4.87 \mathrm{KPa}$
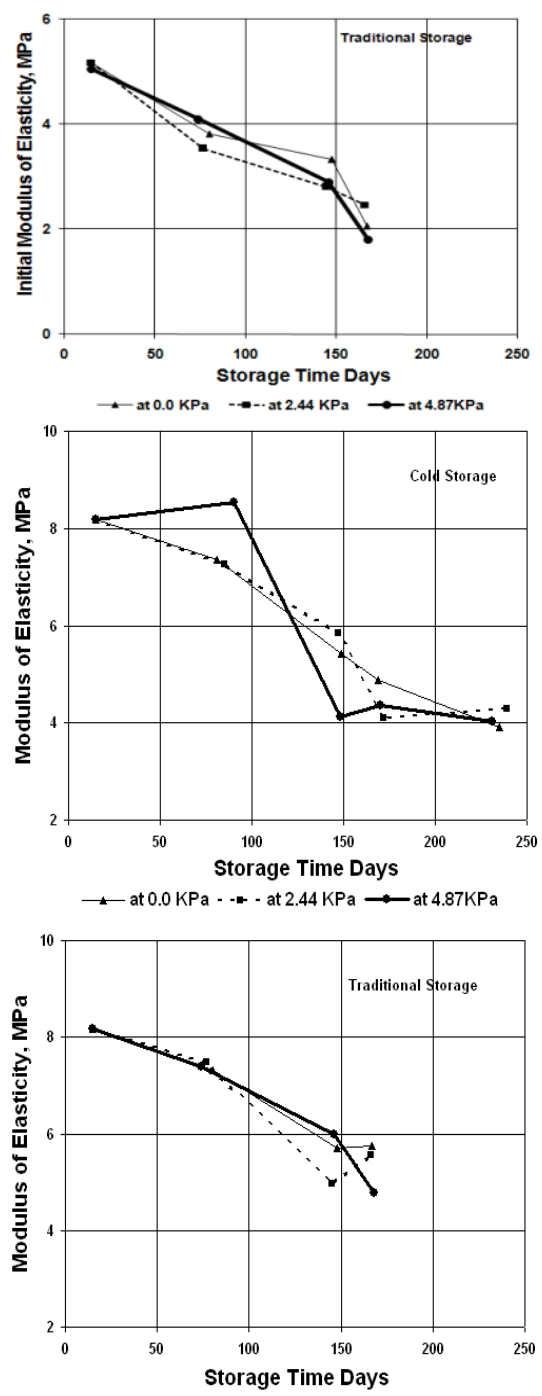

$\rightarrow$ at $0.0 \mathrm{KPa}-\cdots-$ at $2.44 \mathrm{KPa} \rightarrow$ at $4.87 \mathrm{KPa}$

Figure (11): Effect of Storage Time on Initial and Secant Modulus of Elasticity of Sand and Black Soil Cultivar on Two Storage Conditions and at Different Static Load. 
Sand soil
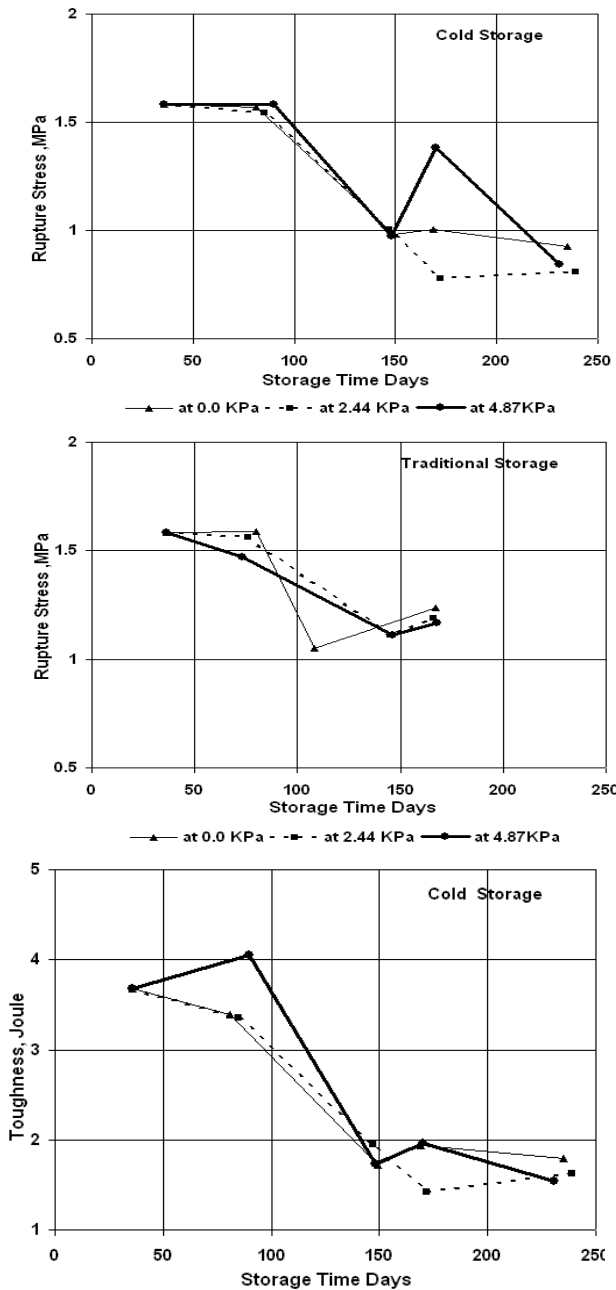

$\longrightarrow$ at $0.0 \mathrm{KPa}---$ at $2.44 \mathrm{KPa} \longrightarrow$ at $4.87 \mathrm{KPa}$

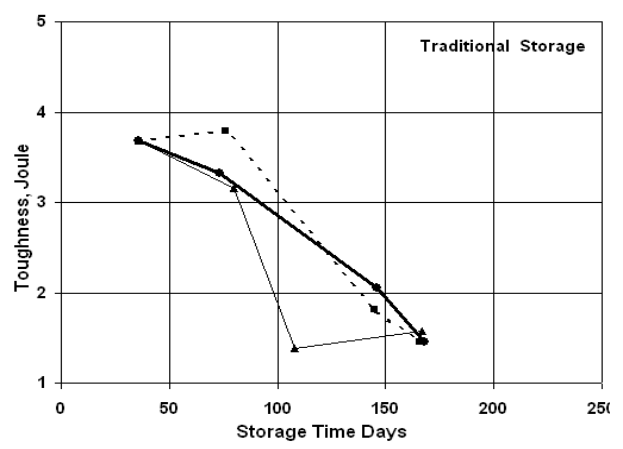

$\longrightarrow$ at $0.0 \mathrm{KPa}---$ at $2.44 \mathrm{KPa} \longrightarrow$ at $4.87 \mathrm{KPa}$
Black Soil
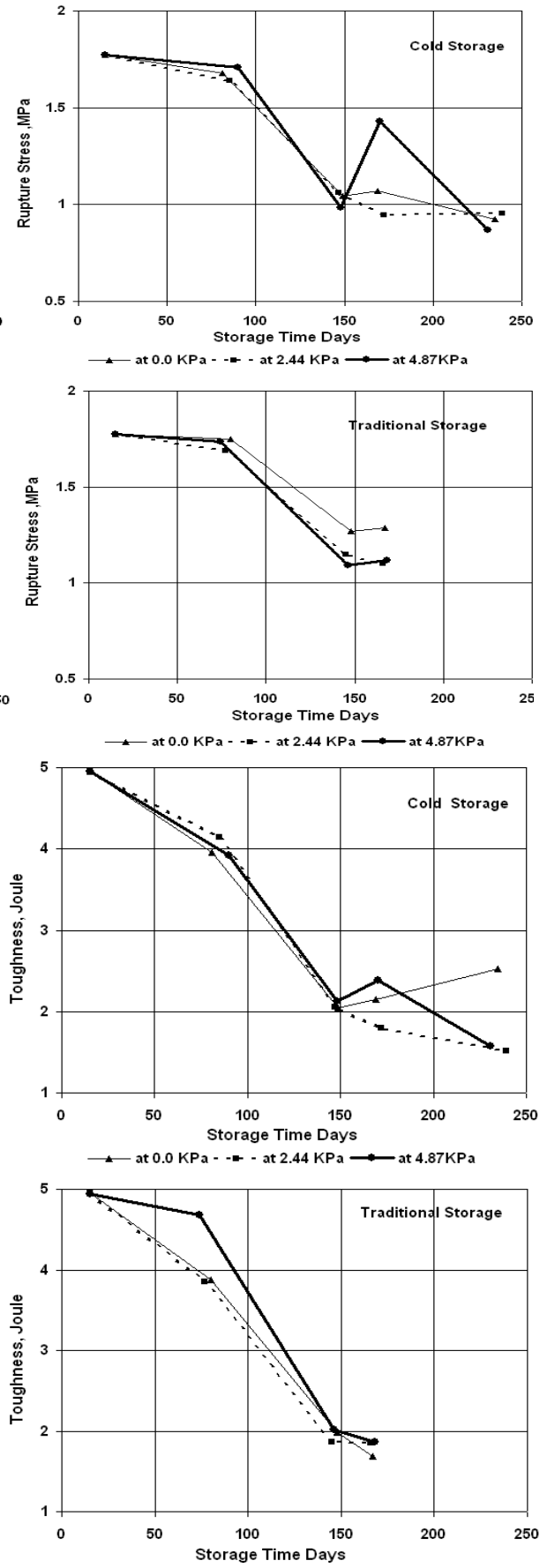

$\longrightarrow$ at $0.0 \mathrm{KPa}---$ at $2.44 \mathrm{KPa} \longrightarrow$ at $4.87 \mathrm{KPa}$

Figure (12): Effect of Storage Time on Rupture Stress and Toughness of Sand and Black Soil Cultivar on Two Storage Conditions and at Different Static Load. 
PROCESS ENGINEERING

\section{For Sand Soils:}

$$
\begin{gathered}
\sigma_{\mathrm{ys}}, \mathrm{MPa}=0.0514 \mathrm{~T}+0.0376 \mathrm{SL}-0.0007 \mathrm{t}+0.0049 \mathrm{M} \\
\ldots \ldots \ldots \ldots \ldots \ldots \mathrm{R}^{2}=0.903, \mathrm{STD}=0.468 \ldots \\
\varepsilon_{\mathrm{ys}}=0.0084 \mathrm{~T}+0.0062 \mathrm{SL}+0.0009 \mathrm{t}+0.0002 \mathrm{M} \\
\ldots \ldots \ldots \ldots \ldots \mathrm{R}^{2}=0.958, \mathrm{STD}=0.046 \ldots
\end{gathered}
$$

$\mathrm{WD}_{\mathrm{ys}}$, Joule $=0.0695 \mathrm{~T}+0.0646 \mathrm{SL}-0.0015 \mathrm{t}+0.0092 \mathrm{M}$

$$
\mathrm{R}^{2}=0.891, \mathrm{STD}=0.711
$$

$\mathrm{E}_{1 \mathrm{~s}}, \mathrm{MPa}=0.0684 \mathrm{~T}+0.0098 \mathrm{SL}-0.0041 \mathrm{t}+0.0275 \mathrm{M}$

$$
\mathrm{R}^{2}=0.798, \mathrm{STD}=2.003 \text {. }
$$

$E_{2 S}, M P a=0.2063 \mathrm{~T}+0.1273 \mathrm{SL}-0.0022 \mathrm{t}+0.0334 \mathrm{M}$

$$
R^{2}=0.916 \mathrm{Std}=2.0539 .
$$

$\sigma_{\mathrm{rs}}, \mathrm{MPa}=0.0546 \mathrm{~T}+0.0399 \mathrm{SL}-0.0007 \mathrm{t}+0.0059 \mathrm{M}$

$$
. \mathrm{R}^{2}=0.941, \mathrm{STD}=0.361 \ldots
$$

$\varepsilon_{\mathrm{rs}}=0.0101 \mathrm{~T}+0.0074 \mathrm{SL}+0.0012 \mathrm{t}+0.0003 \mathrm{M}$

$$
. \mathrm{R}^{2}=0.963, \mathrm{STD}=0.054
$$

$\mathrm{WD}_{\mathrm{rs}}$, Joule $=0.0816 \mathrm{~T}+0.0885 \mathrm{SL}-0.0061 \mathrm{t}+0.02004 \mathrm{M}$

$$
\mathrm{R}^{2}=0.895, \mathrm{STD}=1.124 \ldots
$$

$$
\varepsilon_{\mathrm{ys}}=0.0122 \mathrm{~T}+0.0089 \mathrm{SL}+0.0012 \mathrm{t}
$$

$$
. \mathrm{R}^{2}=0.964, \mathrm{STD}=0.054 \ldots
$$

$\sigma_{\mathrm{ys}}, \mathrm{MPa}=0.0972 \mathrm{~T}+0.0735 \mathrm{SL}-0.0004 \mathrm{t}$

$$
. \mathrm{R}^{2}=0.903, \mathrm{STD}=0.468 \ldots
$$

$\mathrm{WD}_{\mathrm{ys}}$, Joule $=0.2262 \mathrm{~T}+0.1975 \mathrm{SL}-0.0048 \mathrm{t}$

$$
. \mathrm{R}^{2}=0.856, \mathrm{STD}=1.283 \ldots
$$




\section{For Black Soils:}

$$
\begin{array}{r}
\sigma_{\mathrm{yb}}, \mathrm{MPa}=0.0547 \mathrm{~T}+0.0424 \mathrm{SL}-0.0014 \mathrm{t}+0.0056 \mathrm{M} \\
\ldots \ldots \ldots \ldots \ldots \mathrm{R}^{2}=0.932, \mathrm{STD}=0.382 \ldots
\end{array}
$$

$\varepsilon_{\mathrm{yb}}=0.0089 \mathrm{~T}+0.0066 \mathrm{SL}+0.0005 \mathrm{t}+0.0005 \mathrm{M}$

$$
\mathrm{R}^{2}=0.907, \mathrm{STD}=0.069 .
$$

$\mathrm{WD}_{\mathrm{yb}}$, Joule $=0.0858 \mathrm{~T}+0.0749 \mathrm{SL}-0.0029 \mathrm{t}+0.0099 \mathrm{M}$

$$
\mathrm{R}^{2}=0.891, \mathrm{STD}=0.829 . .
$$

$\mathrm{E}_{1 \mathrm{~b}}, \mathrm{MPa}=0.0885 \mathrm{~T}+0.0690 \mathrm{SL}-0.0109 \mathrm{t}+0.0310 \mathrm{M}$

$$
\mathrm{R}^{2}=0.816, \mathrm{STD}=2.269 \ldots
$$

$\mathrm{E}_{2 \mathrm{~b}}, \mathrm{MPa}=0.2248 \mathrm{~T}+0.1825 \mathrm{SL}-0.0088 \mathrm{t}+0.0373 \mathrm{M}$

$$
\mathrm{R}^{2}=0.926, \mathrm{STD}=2.135 \ldots(21)
$$

$\sigma_{\mathrm{rb}}, \mathrm{MPa}=0.0591 \mathrm{~T}+0.0484 \mathrm{SL}-0.0016 \mathrm{t}+0.0067 \mathrm{M}$

$$
\mathrm{R}^{2}=0.943, \mathrm{STD}=0.396 \ldots
$$

$$
\begin{aligned}
\varepsilon_{\mathrm{rb}}=0.0099 \mathrm{~T}+0.0076 \mathrm{SL}+0.0004 \mathrm{t}+0.0009 \mathrm{M} \\
\ldots \ldots \ldots \ldots \ldots \ldots \mathrm{R}^{2}=0.917, \mathrm{STD}=0.086 .
\end{aligned}
$$

$\mathrm{WD}_{\mathrm{rb}}$, Joule $=0.0915 \mathrm{~T}+0.0972 \mathrm{SL}-0.0091 \mathrm{t}+0.0268 \mathrm{M}$

$$
\mathrm{R}^{2}=0.867, \mathrm{STD}=1.709 \text {. }
$$

\section{REFRENCES}

Baritelle, A.t., G.M. Hyde, (1999). Effect of tuber size on the failure properties of potato tissue. Trans. of the ASAE 42, 159-161.

Burton WG.(1989). Post-harvest physiology. In: WG BURTON. Ed. The Potato, $3^{\text {rd }}$ Ed. Longman Singapore Publishers (Pte) Ltd, Singapore.423 -522. 
Fekete, A, and P. Sass. (1994). Elasticity characteristics of fruits. International symposium on postharvest treatment of horticultural crops. Proceedings a conference held in Kecskemet, Hungary, 30 August -3 September 1993. Acta Horticulture, 368: 199-205.

Ghadge, A.D.; M.G. Britton; and D. S. Sayas (1989). Moisture content determination for potatoes. Transactions of the ASAE, 32(5): 17441746.

Konstankiewicz ,K., K. Pawlak and A.Zdunek. (2001). Influence of structural parameters of potato tuber cells on their mechanical properties. International Agrophysics, 2001,15, 243-246.

Mohsenin, N.N. (1986). Physical Properties of Plant and Animal Materials. Gordon and Breach Science Publishes. New York, USA.

NPC, (Journal of National Potato Council), Jul 2016, Washington, D.C., USA).

الملخص العربي

سلوك اختبارات الإختراق والإجهاد_الإنفعال لارنات البطاطس أثناء التخزين.

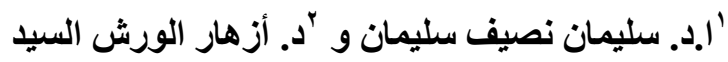

يهدف البحث إلى دراسة سلوك اختبار الاختراق والإجهاد_الإنفعال لدرنات البطاطس و التي تم

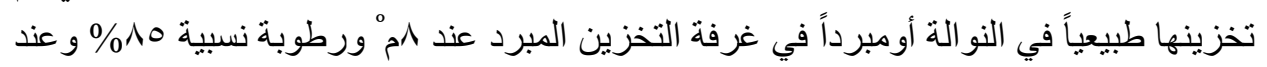

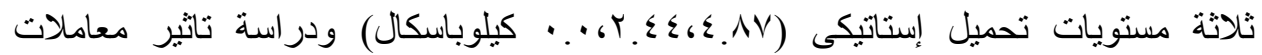

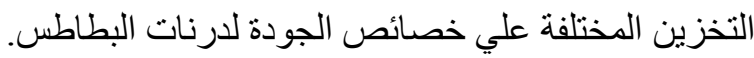

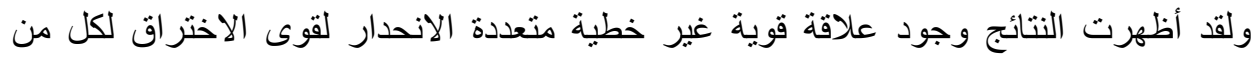

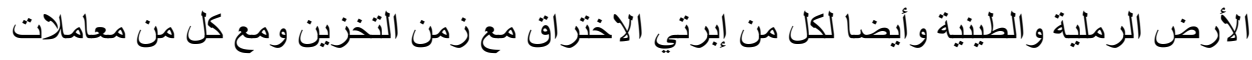

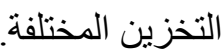

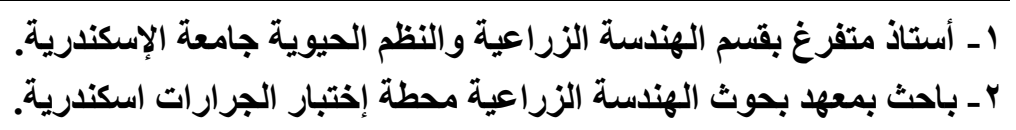


تم قياس بار امترات اختبار الإجهاد_الانفعال و دراسة نأثثر زمن التخزين وظروف التخزين علي بار امتر ات الإجهاد ـ الانفعال المختلفة.

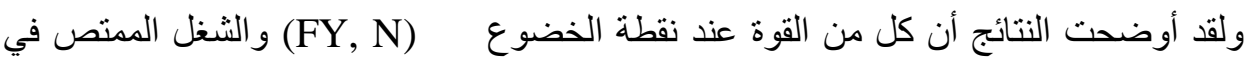

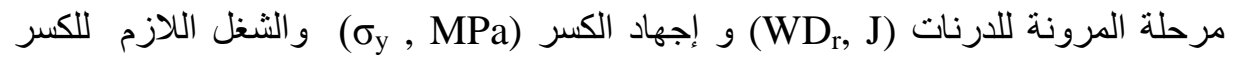

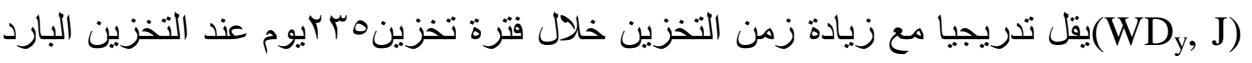

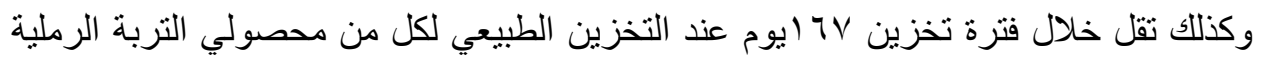
و الطينية علي التوالي. 